\title{
Table of Contents / Table des matières
}

Canada I50. Bound by Three Oceans: Reading, Writing, Printing and Publishing in Canada since Confederation / Canada I50. Un pays relié d'un océan à l'autre: lire, écrire, imprimer \& publier au Canada depuis 1867

Guest Editors / Rédactrices

RUTH-ELLEN ST. ONGE, JANET FRISKNEY, AND/ET MYRA TAWFIK

Introduction: Canada I50. Bound by Three Oceans: Reading, Writing, Printing and Publishing in Canada since Confederation

RUTH-ELLEN ST. ONGE, JANET FRISKNEY, AND MYRA TAWFIK

Introduction: Canada I50. Un pays relié d'un océan à l'autre: lire, écrire, imprimer \& publier au Canada depuis 1867 RUTH-ELLEN ST. ONGE, JANET FRISKNEY, ET MYRA TAWFIK

Marie Tremaine Medal

The Struggle behind "Struggle and Story": A Canada I50 Exhibition at the Thomas Fisher Rare Book Library PEARCE J. CAREFOOTE

The Geopolitics of Nineteenth-Century Canadian Copyright, as seen by some British Authors

MEERA NAIR

Tried, Tested, but not Proved: The Home Cook Book and the Development of a Canadian Culinary Identity MELISSA MCAFEE AND ASHLEY SHIFFLETT MCBRAYNE

Un nationalisme tourné vers l'Amérique et les colonies:

l'exportation du «Roman canadien» des Éditions

Édouard Garand

MARIE-HÉLÈNE CONSTANT ET CAROLINE LORANGER

La Revue moderne, creuset de la littérature en régime médiatique dans les années I950 au Québec 


\section{Books in Review / Comptes rendus}

KRISTINE SMITKA and/et STÉPHANIE BERNIER

Manon Auger, Les journaux intimes et personnels au Québec.

Poétique d'un genre littéraire incertain (Adrien Rannaud)

Thierry Groensteen, La bande dessinée au tournant (Philippe Rioux)

David Martens, Jean-Pierre Montier, Anne Reverseau, dir., L'Écrivain vu par la photographie: formes, usages, enjeux (Laureline Meizel)

Dictionnaire des intellectuel.les au Québec, sous la direction

d'Yvan Lamonde, de Marie-Andrée Bergeron, de

Michel Lacroix et de Jonathan Livernois (Pierre Hébert)

Antoine Compagnon, Les Chiffonniers de Paris

(Valérie Stiénon)

Sophie Dubois, Refus global. Histoire d'une réception partielle (Édith-Anne Pageot)

Carl Dair, Epistles to the Torontonians: With Articles from the Canadian Printer \& Publisher (John Shoesmith)

Gayle Garlock, Canadian Binders' Tickets and Booksellers' Labels (Thomas E. Kinsella)

Elizabeth Groeneveld, Making Feminist Media: Third-Wave Magazines on the Cusp of the Digital Age (Marcelle Kosman)

Sandra Alston and C.M. Blackstock, Eds., "Another World": William Ord Mackenzie's Sojourn in Canada, I839-43

(Michael Peterman)

Elizabeth Popham and David G. Pitt, Eds., E.J. Pratt: Letters (Sandra Campbell)

Renate Vervoort, Brueghel's Witches: Witchcraft Images in the Low Countries between 1450 and 1700 (Andrew Gow) 
Elaine Dewar, The Handover: How Bigwigs and Bureaucrats Transferred Canada's Best Publisher and the Best Part of Our Literary Heritage to a Foreign Multinational (Kristine Smitka)

Matthew Rubery, The Untold Story of the Talking Book (Jillian Richardson)

Means and Purposes: A Suggestion to Our Members and Friends

'Qui veut la fin veut les moyens' 404

Information for Authors 405 Information à l'intention de nos collaborateurs 406 LGBTQ+ print in Canada: Overviews and perspectives

L’imprimé LGBTQ+ au Canada et ailleurs : bilans et perspectives 